\title{
Increased calcium intake is associated lower serum 25-hydroxyvitamin D levels in subjects with adequate vitamin D intake: a population-based observational study
}

\author{
Rolf Jorde ${ }^{1,2^{*}}$ and Guri Grimnes ${ }^{1,2}$
}

\begin{abstract}
Background: There are indications that an increased intake of calcium has a vitamin D sparing effect, which might be explained by a decreased catabolism of 25-hydroxyvitamin $\mathrm{D}(25(\mathrm{OH}) \mathrm{D})$. However, there are only a few studies where this has been examined.

Method: In the seventh survey of the Tromsø study, serum 25(OH)D and parathyroid hormone were measured, and questionnaires on calcium and vitamin D intakes filled in.

Results: There were significant interactions between sex, calcium and vitamin $D$ intakes regarding serum 25(OH)D level. The analyses were therefore done stratified. In males there was, regardless of vitamin D intake, a significant decrease in serum 25(OH)D with increasing calcium intake. The difference in serum 25(OH)D between those with the highest and lowest calcium intakes was approximately $10 \%$. In the females, there was in subjects with low vitamin D intake $(<7 \mu \mathrm{g} / \mathrm{d})$ a significant increase in serum 25(OH)D with increasing calcium intake, which could not be explained by secondary hyperparathyroidism. In females with higher vitamin D intakes, increasing calcium intake was associated with lower serum 25(OH)D levels.
\end{abstract}

Conclusions: There is, at least in subjects with an adequate vitamin D intake, a negative association between calcium intake and serum 25(OH)D.

Keywords: Calcium, Parathyroid hormone, Vitamin D, 25-hydroxyvitamin D

\section{Background}

Vitamin D is obtained from the diet or supplements and also from production in the skin upon sun exposure. Vitamin D is first hydroxylated in the liver to 25hydroxyvitamin $\mathrm{D}(25(\mathrm{OH}) \mathrm{D})$, and then in the kidneys to 1,25 -dihydroxyvitamin $\mathrm{D}\left(1,25(\mathrm{OH})_{2} \mathrm{D}\right)$ which is the active form of the vitamin. The main biological effect of 1 ,

\footnotetext{
* Correspondence: rolf.jorde@uit.no

${ }^{1}$ Tromsø Endocrine Research Group, Department of Clinical Medicine, UiT The Arctic University of Norway, Tromsø, Norway

2Division of Internal Medicine, University Hospital of North Norway, 9038 Tromsø, Norway
}

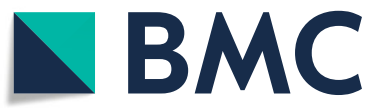

(c) The Author(s). 2020 Open Access This article is licensed under a Creative Commons Attribution 4.0 International License, which permits use, sharing, adaptation, distribution and reproduction in any medium or format, as long as you give appropriate credit to the original author(s) and the source, provide a link to the Creative Commons licence, and indicate if changes were made. The images or other third party material in this article are included in the article's Creative Commons licence, unless indicated otherwise in a credit line to the material. If material is not included in the article's Creative Commons licence and your intended use is not permitted by statutory regulation or exceeds the permitted use, you will need to obtain permission directly from the copyright holder. To view a copy of this licence, visit http://creativecommons.org/licenses/by/4.0/. The Creative Commons Public Domain Dedication waiver (http://creativecommons.org/publicdomain/zero/1.0/) applies to the data made available in this article, unless otherwise stated in a credit line to the data.

$25(\mathrm{OH})_{2} \mathrm{D}$ is to increase the intestinal calcium absorption. The 25-hydroxylation is substrate driven, whereas the 1hydroxylation is tightly regulated by parathyroid hormone (PTH). If the serum calcium level falls, the serum PTH level increase stimulating secretion of $1,25(\mathrm{OH})_{2} \mathrm{D}$ and thereby restoration of the serum calcium level [1].

The serum level of $25(\mathrm{OH}) \mathrm{D}$ is generally considered as the best marker of a subjects vitamin D status, due to its ease of measurement, long half-life and correlation with known vitamin $\mathrm{D}$ effects. However, there is no consensus as to what can be considered an adequate or optimal serum 25(OH)D level [2,3]. 
Vitamin D deficiency may in children lead to rickets and in adults to osteomalacia. At least for the prevention of rickets, it appears that a high calcium intake can compensate for a low vitamin $\mathrm{D}$ intake and vice versa [4]. There are also indications that there might be an interaction between these intakes, so that a high calcium intake cause an increase in the serum $25(\mathrm{OH}) \mathrm{D}$ level as reviewed by Heaney [5]. Thus, rats fed a high calcium diet had a higher serum 25(OH)D level than rats on a low calcium diet [6], and in rats the inactivation of $25(\mathrm{OH}) \mathrm{D}$ in the liver is increased by calcium deprivation [7]. Furthermore, in subjects with primary or secondary hyperparathyroidism Davies et al. have shown that the half-life of $25(\mathrm{OH}) \mathrm{D}$ was lower in those with high 1 , $25(\mathrm{OH})_{2} \mathrm{D}$ levels. This could be explained by 1 , $25(\mathrm{OH})_{2} \mathrm{D}$ inducing the 24-hydroxylase which is the enzyme starting the degradation process of $25(\mathrm{OH}) \mathrm{D}$ as well as $1,25(\mathrm{OH})_{2} \mathrm{D}$ [8]. Based on these observations the concept of a vitamin D sparing effect of a high calcium intake has been suggested [9].

However, observational studies on calcium and vitamin D intakes regarding serum 25(OH)D levels have been equivocal. Thus, Olmos et al. found the serum $25(\mathrm{OH}) \mathrm{D}$ level to be positively correlated with dairy intake in 1811 individuals [10], as did Kinyamu in 243 women [11]. On the other hand, this was not confirmed by Hill et al. in a group of 1015 adolescents from Northern Ireland [12] nor by Andersen et al. in a group of 247 Pakistani living in Denmark and with low serum 25(OH)D levels [13]. Similarly, randomized controlled trials (RCTs) have shown a large and positive effect by calcium supplementation on the $25(\mathrm{OH}) \mathrm{D}$ response to vitamin D supplementation in one study [14], which has not been confirmed in others [15-18].

In the last Tromsø study serum 25(OH)D was measured and questionnaires on intakes of vitamin $\mathrm{D}$ and calcium filled in by more than 11,000 subjects. In a sub-group of 1917 subjects serum PTH was measured as well. This gave us the opportunity to evaluated interrelationships between these intakes regarding serum 25(OH)D level, and to evaluate if these relationships could be explained by secondary hyperparathyroidism, which to our knowledge has not been done in a huge cohort before.

\section{Methods}

\section{Study design and participants}

The Tromsøs study is a population-based health survey performed in Tromsø, Northern Norway at $69^{\circ}$ North. The first survey was performed in 1974 and the seventh survey in $2015 / 2016$. Originally the study focused on cardiovascular diseases and their prevention, but later surveys have included a wide range of tests and analyses [19]. In the seventh survey all citizens older than 40 years and living in the municipality of Tromsø were invited, and $64.7 \%(21,083)$ attended. The subjects filled in a general health questionnaire including intakes of vitamin $\mathrm{D}$ and calcium supplements, sunny vacation(s) last two months, and use of solarium. Intakes of vitamin $\mathrm{D}$ and calcium were estimated based on a validated food frequency questionnaire that included 261 questions on food items, meals, and beverages [20, 21]. Non-fasting blood samples were drawn; height and weight were measured wearing light clothing, and body mass index (BMI) calculated as $\mathrm{kg} / \mathrm{m}^{2}$.

\section{Biochemical analyses}

All biochemical analyses were performed at the Department of Medical Biochemistry, University Hospital of North Norway. Serum 25(OH)D was measured in all subjects and determined by an in-house-developed LC/ MS-MS method as previously described in detail [22]. The laboratory takes part in the external quality program DEQAS. Serum PTH and calcium were measured in a subgroup of 3769 subjects who also had attended the fourth survey in 1994/1995. Serum PTH was analysed with an electrochemiluminescence immunoassay using an automated clinical chemistry analyser (Cobas 6000 , Roche). Serum calcium was measured by an automated analyser (Modular P, Roche Diagnostics, Mannheim, Germany) with reagents from Boehringer Mannheim. Reference ranges for serum PTH were 1.1-6.8 pmol/L for those $<51$ years and $1.1-7.5 \mathrm{pmol} / \mathrm{L}$ for those $>50$ years, and for serum calcium $2.20-2.50 \mathrm{mmol} / \mathrm{L}$.

\section{Statistical analyses}

Normal distribution was evaluated by visual inspection of histograms and by calculation of skewness and curtosis, and considered normal for all dependent variables except for serum PTH. Serum PTH was therefore normalized by log transformation before use as dependent variable. Comparisons between groups were performed with Student's t-test. For evaluation of predictors of serum $25(\mathrm{OH}) \mathrm{D}$ a linear regression model was used with covariates as indicated in the table. Interactions between calcium and vitamin $\mathrm{D}$ intake groups, gender and age regarding the serum $25(\mathrm{OH}) \mathrm{D}$ level were evaluated with a general linear model. Linear trends were evaluated with linear regression with adjustments for sex, age, BMI and month of blood sampling (with the use of dummy variables) as indicated in the tables.

All data presented in this study, including the biochemical analyses, are from the seventh survey of the Tromsø study. The data are shown as mean $(95 \% \mathrm{CI})$. All tests were done two-sided, and a $P$-value $<0.05$ was considered statically significant. The Bonferroni correction for multiple comparisons was used as indicated in the tables. 


\section{Results}

\section{Main study}

A total of 13,743 subjects had completed datasets regarding vitamin $\mathrm{D}$ and calcium intakes and valid serum 25(OH)D measurement. Among these, 2466 had been on a recent sunny holiday and among the remainder, 27 were using solarium on a regular basis, leaving 11,250 subjects (5982 females and 5268 males) who were included in the present analyses. Among these, 6.7\% used calcium tablets daily, and 37.2\% used cod liver oil and/or omega-3 fish oil capsules and/or other supplements with vitamin $\mathrm{D}$ on a daily basis, and $12.7 \%$ were daily smokers. The mean serum $25(\mathrm{OH}) \mathrm{D}$ level was 62.2 $\mathrm{nmol} / \mathrm{L}$, and $29.6 \%$ of the subjects had serum $25(\mathrm{OH}) \mathrm{D}<$ $50 \mathrm{nmol} / \mathrm{L}$. Other characteristics are shown in Table 1.

In a linear regression model with serum $25(\mathrm{OH}) \mathrm{D}$ as dependent variable, female gender, age and vitamin $\mathrm{D}$ intake were significant positive predictors of serum $25(\mathrm{OH}) \mathrm{D}$, whereas BMI and calcium intake were significant negative predictors (Supplemental Table 1).

However, there was a significant interaction between calcium and vitamin D intakes regarding 25(OH)D $(P<$ $0.001)$. Furthermore, when doing this analysis stratified for vitamin $\mathrm{D}$ intake, there was in the lowest vitamin $\mathrm{D}$ intake group $(<7 \mu \mathrm{g} / \mathrm{d})$ a significant interaction between sex and calcium intake regarding serum 25(OH)D $(P<0.01)$. The relations between serum $25(\mathrm{OH}) \mathrm{D}$, vitamin $\mathrm{D}$ and calcium intakes were therefore analysed for all subjects together as well as sex stratified. There were no interactions with age.

With increasing vitamin $\mathrm{D}$ intake there was a significant increase in serum 25(OH)D in all calcium intake groups in both genders. With increasing calcium intake there was in the low vitamin D intake group $(<7 \mu \mathrm{g} / \mathrm{d})$ a significant increase in serum $25(\mathrm{OH}) \mathrm{D}$ in the females but not in the males. In the males and when both genders were analysed together, there was with increasing calcium intake a non-significant decrease in serum $25(\mathrm{OH}) \mathrm{D}$ in the $7-13.9 \mu \mathrm{g}$ vitamin $\mathrm{D} / \mathrm{d}$ intake group, whereas in the two highest vitamin $\mathrm{D}$ intake groups (14.0-20.9 and > 20.9 $\mu \mathrm{g} / \mathrm{d})$ there was a significant decrease in serum $25(\mathrm{OH}) \mathrm{D}$. In these two vitamin D intake groups the difference in serum $25(\mathrm{OH}) \mathrm{D}$ between those with the lowest and highest calcium intake was $~ 10 \%$ (Table 2 and Figs. 1, 2 and 3).

\section{Sub-group study}

A total of 1917 subjects (1089 females and 828 males) had valid data-sets as above, valid serum PTH measurement and serum calcium $<2.51 \mathrm{nmol} / \mathrm{L}$, and were included in the sub-group analyses. Among these, $11.8 \%$ used calcium tablets daily, and 53.2\% used cod liver oil and/or omega-3 fish oil capsules and/or other supplements with vitamin $\mathrm{D}$ on a daily basis. Their other baseline characteristics are shown in Table 1. In general,

Table 1 Characteristics of the participants in the main cohort and the sub-study

\begin{tabular}{|c|c|c|c|}
\hline & All subjects & Males & Females \\
\hline \multicolumn{4}{|l|}{ Main cohort ${ }^{a}$} \\
\hline $\mathrm{N}$ & 11,250 & 5268 & 5982 \\
\hline Age (years) & $58.3(58.1,58.5)$ & $58.5(58.2,58.8)$ & $58.0(57.7,58.3)^{*}$ \\
\hline BMI $\left(\mathrm{kg} / \mathrm{m}^{2}\right)$ & $27.3(27.2,27.4)$ & $27.7(27.6,27.8)$ & $26.9(26.8,27.1)^{* * *}$ \\
\hline Serum 25(OH)D (nmol/L) & $62.2(62.0,62.7)$ & $59.2(58.7,59.8)$ & $65.1(64.5,65.6)^{* * *}$ \\
\hline Vitamin D intake $(\mathrm{ug} / \mathrm{d})^{c}$ & $14.1(14.0,14.3)$ & $14.5(14.2,14.7)$ & $13.9(13.6,14.1)^{* *}$ \\
\hline Calcium intake $(\mathrm{mg} / \mathrm{d})^{c}$ & $1188(1177,1199)$ & $1247(1231,1264)$ & $1136(1121,1151)^{* * *}$ \\
\hline \multicolumn{4}{|l|}{ Sub-study } \\
\hline$N$ & 1917 & 828 & 1089 \\
\hline Age (years) & $70.2(69.8,70.6)$ & $70.7(70.3,71.3)$ & $69.9(69.3,70.4)$ \\
\hline BMI $\left(\mathrm{kg} / \mathrm{m}^{2}\right)$ & $27.4(27.2,27.6)$ & $27.6(27.3,27.8)$ & $27.4(27.1,27.6)$ \\
\hline Serum 25(OH)D (nmol/L) & $68.2(67.3,69.2)$ & $65.3(64.0,66.7)$ & $70.4(69.2,71.7)^{* * *}$ \\
\hline Serum PTH (pmol/L) & $5.8(5.7,5.9)$ & $5.9(5.7,6.0)$ & $5.8(5.7,5.9)$ \\
\hline Serum calcium (mmol/L) & $2.36(2.36,2.36)$ & $2.35(2.35,2.36)$ & $2.37(2.36,2.37)^{* * *}$ \\
\hline Vitamin D intake $(\mathrm{ug} / \mathrm{d})^{c}$ & $14.9(14.4,15.4)$ & $15.2(14.5,15.9)$ & $14.6(14.0,15.3)$ \\
\hline Calcium intake $(\mathrm{mg} / \mathrm{d})^{c}$ & $1168(1140,1195)$ & $1199(1157,1241)$ & $1144(1108,1181)$ \\
\hline
\end{tabular}

${ }^{*} P<0.05,{ }^{* *} P<0.01,{ }^{* * *} P<0.001$. Student's t-test versus males

${ }^{a}$ Subjects in the Troms $\varnothing$ study with valid food frequency questionnaires, serum $25(\mathrm{OH}) \mathrm{D}$ measurement, not been on a sunny vacation last 2 months, and not taking solarium regularly

${ }^{\mathrm{b}}$ As in the main cohort but with valid serum PTH measurement and with serum calcium $<2.51 \mathrm{mmol} / \mathrm{L}$

Including supplements

The data are mean $(95 \% \mathrm{Cl})$. The $P$ values are not adjusted for multiple testing 
Table 2 Serum 25(OH)D in relation to calcium and vitamin D intakes in all subjects and gender specific in the 11,250 subjects in the main cohort

\begin{tabular}{|c|c|c|c|c|c|c|c|c|}
\hline & \multicolumn{2}{|c|}{$\begin{array}{l}\text { Calcium intake§ } \\
<500 \mathrm{mg} / \mathrm{d}\end{array}$} & \multicolumn{2}{|c|}{$\begin{array}{l}\text { Calcium intake§ } \\
500-999 \mathrm{mg} / \mathrm{d}\end{array}$} & \multicolumn{2}{|c|}{$\begin{array}{l}\text { Calcium intake } \\
1000-1499 \mathrm{mg} / \mathrm{d}\end{array}$} & \multicolumn{2}{|c|}{$\begin{array}{l}\text { Calcium intake } \\
>1499 \mathrm{mg} / \mathrm{d}\end{array}$} \\
\hline & $\mathrm{n}$ & $\begin{array}{l}\text { Serum 25(OH)D } \\
(\mathrm{nmol} / \mathrm{L})\end{array}$ & $n$ & $\begin{array}{l}\text { Serum 25(OH)D } \\
\text { (nmol/L) }\end{array}$ & $n$ & $\begin{array}{l}\text { Serum } 25(\mathrm{OH}) \mathrm{D} \\
(\mathrm{nmol} / \mathrm{L})\end{array}$ & $\mathrm{n}$ & $\begin{array}{l}\text { Serum 25(OH)D } \\
\text { (nmol/L) }\end{array}$ \\
\hline \multicolumn{9}{|l|}{ All subjectsł } \\
\hline \multicolumn{9}{|c|}{ Vitamin D intake $(\mathrm{ug} / \mathrm{d}) \S$} \\
\hline$<7.0$ & 444 & $56.2(54.3,58.0)$ & 1396 & $54.8(53.8,56.7)$ & 874 & $56.7(55.2,58.1)$ & 302 & $56.7(54.3,59.1)$ \\
\hline $7.0-13.9$ & 223 & $60.8(58.1,63.5)$ & 1360 & $60.8(59.8,61.9)$ & 1531 & $59.7(58.7,60.6)$ & 943 & $57.8(56.5,59.0) \#$ \\
\hline 14.0-20.9 & 69 & $69.1(64.0,74.1)$ & 513 & $69.0(67.3,70.8)$ & 624 & $66.6(65.0,68.2)$ & 553 & $62.5(60.8,64.2) \#^{* *}$ \\
\hline$>20.9$ & 77 & $76.2(71.1,81.2) \dagger$ & 666 & $74.3(72.7,76.0) \dagger$ & 871 & $72.5(71.2,73.8) \dagger$ & 804 & $69.6(68.2,71.1) \#^{* *} \dagger$ \\
\hline \multicolumn{9}{|l|}{ Males $\neq$} \\
\hline \multicolumn{9}{|c|}{ Vitamin D intake $(\mathrm{ug} / \mathrm{d}) \S$} \\
\hline$<7.0$ & 165 & $54.5(51.7,57.3)$ & 530 & $52.3(50.7,53.9)$ & 363 & $52.3(50.3,54.2)$ & 139 & $49.8(47.1,52.6)$ \\
\hline $7.0-13.9$ & 93 & $57.3(53.0,61.6)$ & 635 & $57.3(55.8,58.8)$ & 815 & $56.8(55.6,58.1)$ & 536 & $54.4(52.8,56.0)$ \\
\hline $14.0-20.9$ & 29 & $62.5(57.4,67.7)$ & 208 & $66.6(63.7,69.5)$ & 284 & $62.6(60.5,64.7)$ & 321 & $59.0(56.9,61.1) \#^{* *}$ \\
\hline$>20.9$ & 32 & $77.7(68.9,86.5) \dagger$ & 286 & $72.3(69.9,74.6) \dagger$ & 401 & $70.5(68.7,72.4) \dagger$ & 431 & $65.9(64.1,67.7) \#^{* *} \dagger$ \\
\hline \multicolumn{9}{|l|}{ Females $\neq$} \\
\hline \multicolumn{9}{|c|}{ Vitamin D intake $(\mathrm{ug} / \mathrm{d}) \S$} \\
\hline$<7.0$ & 279 & $57.2(54.7,59.7)$ & 866 & $56.4(55.0,57.7)$ & 511 & $59.8(57.8,61.8)$ & 163 & $62.6(59.1,66.2) \#^{*}$ \\
\hline $7.0-13.9$ & 130 & $63.4(59.9,66.8)$ & 725 & $64.0(62.5,65.5)$ & 716 & $62.9(61.5,64.4)$ & 407 & $62.2(60.4,64.1)$ \\
\hline $14.0-20.9$ & 40 & $73.9(66.2,81.6)$ & 305 & $70.7(68.5,73.0)$ & 340 & $70.0(67.6,72.3)$ & 232 & $67.4(64.6,70.2)$ \\
\hline$>20.9$ & 45 & $75.1(68.9,81.4) \dagger$ & 380 & $75.9(73.7,78.1) \dagger$ & 470 & $74.2(72.4,76.0)+$ & 373 & $73.9(71.8,76.1) \dagger$ \\
\hline
\end{tabular}

$\# P<0.01$. Linear trend for serum $25(\mathrm{OH}) \mathrm{D}$ across calcium intake groups without adjustments

${ }^{*} P<0.05,{ }^{* *} P<0.01$. Linear trend for serum $25(\mathrm{OH}) \mathrm{D}$ across calcium intake groups with sex, age, BMI and month of blood sampling (using dummy variables) as covariates

$+P<0.001$. Linear trend for serum 25(OH)D across vitamin D intake groups without adjustments as well as with sex, age, BMI and month of blood sampling (using dummy variables) as covariates

\# Subjects in the Troms $\varnothing$ study with valid food frequency questionnaires, serum $25(\mathrm{OH}) \mathrm{D}$ measurement, not been on a sunny vacation last 2 months, and not taking solarium regularly

§Including supplements

The data are mean $(95 \% \mathrm{Cl})$. The $P$ values are adjusted for multiple testing with a factor of 4

these subjects were older and had higher serum 25(OH)D levels than those in the main cohort.

As expected the serum PTH levels were highest in the subjects with the lowest calcium and vitamin D intakes. However, this was only significant for a few of the vitamin $\mathrm{D}$ and calcium intake subgroups (Table 3). As in the main study there was in the females a significant $(P<0.001)$ increase in serum $25(\mathrm{OH}) \mathrm{D}$ with increasing calcium intake in those with a low vitamin D intake, whereas there in both genders was a decrease in serum $25(\mathrm{OH}) \mathrm{D}$ with increasing calcium intake in those with higher vitamin D intakes (Table 4). The same pattern was seen if dividing the cohort in subjects with serum PTH below or above $5.35 \mathrm{pmol} / \mathrm{L}$ (the median PTH level), which is illustrated for the females in Figs. 4 and 5.

\section{Discussion}

In the present study we have found a negative association between calcium intake and serum 25(OH)D, except in females with a low vitamin D intake where the association was positive. Furthermore, these associations were seen in subjects with low as well as high serum PTH levels.

Our results are at difference with previous observational studies on calcium intake and serum 25(OH)D [14-18]. There are two likely explanations for this. Firstly, there was an interaction between calcium and vitamin $\mathrm{D}$ intakes as well as between genders regarding serum $25(\mathrm{OH}) \mathrm{D}$, and analysing the cohorts without proper stratification as in our study could possibly mask the true relations. Furthermore, the difference in serum 25(OH)D level between those with high and low calcium intakes was approximately $10 \%$, and accordingly, a large number of subjects need to be included, as in our study, to show significant effects.

It is difficult to find a plausible explanation for the mainly negative association between calcium intake and serum $25(\mathrm{OH}) \mathrm{D}$. One could hypothesize that in a 


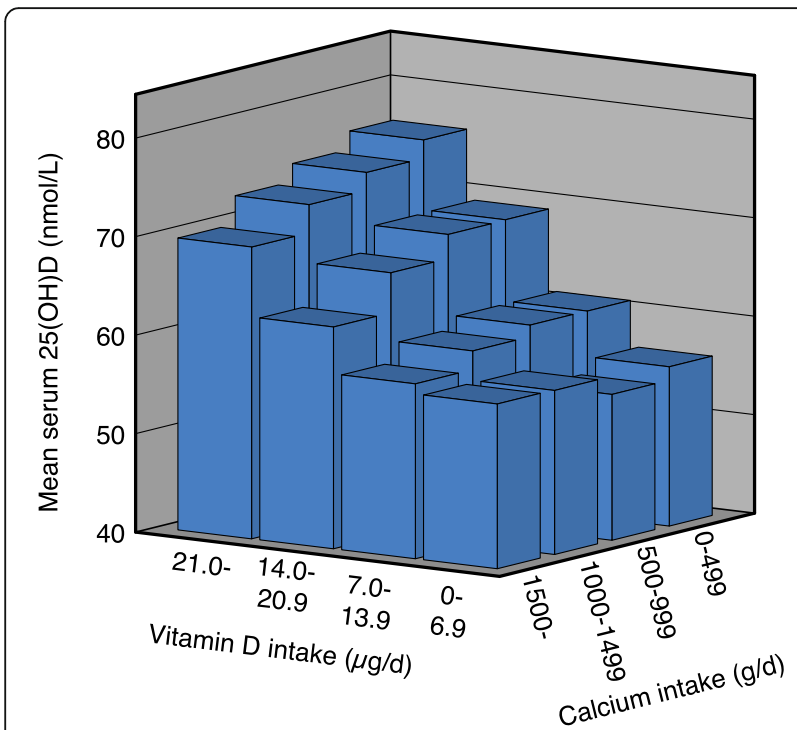

Fig. 1 Serum 25(OH)D in relation to vitamin D and calcium intakes in 11,250 subjects who have not been on a sunny vacation last two months, and not taking solarium regularly

situation with a low calcium intake it would be important for the body to conserve its 25(OH)D stores and therefore reduce the 24-hydroxylation of $25(\mathrm{OH}) \mathrm{D}$ to the inactive $24,25(\mathrm{OH})_{2} \mathrm{D}$ form. However, low calcium intake and thereby low serum calcium levels stimulate the PTH secretion which increases the renal 1-hydroxylation of $25(\mathrm{OH}) \mathrm{D}$ to the active form 1 , $25(\mathrm{OH})_{2} \mathrm{D}$ which in turn increases the intestinal calcium absorption. This process cause removal of $25(\mathrm{OH}) \mathrm{D}$ from the circulation. Additionally, $1,25(\mathrm{OH})_{2} \mathrm{D}$ activates the $24-$

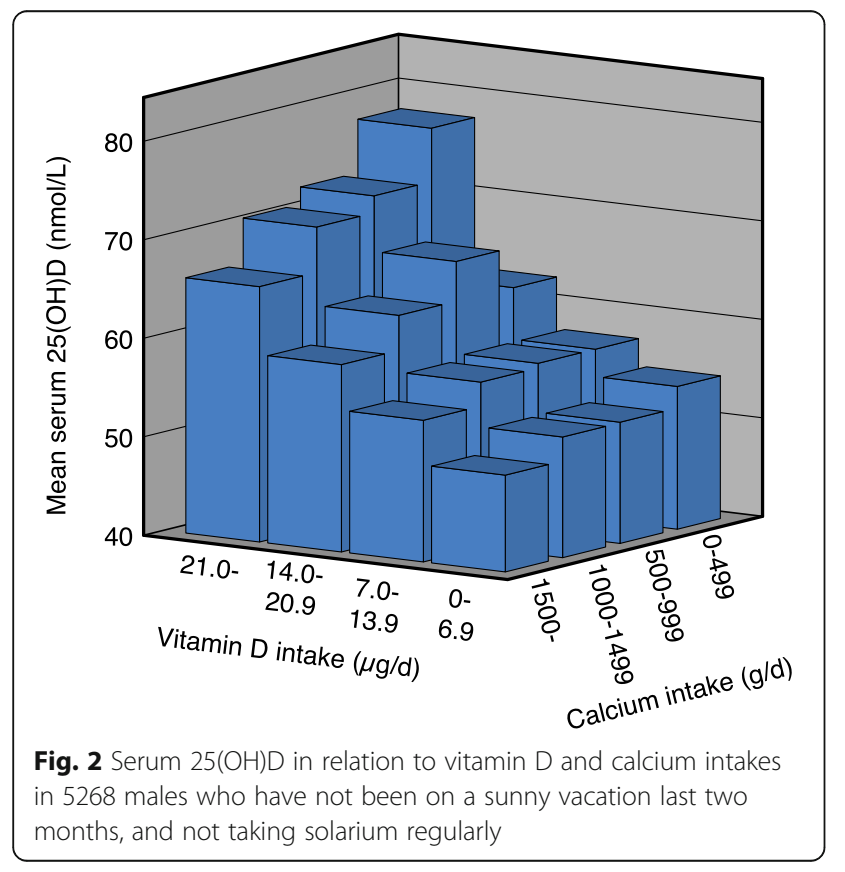

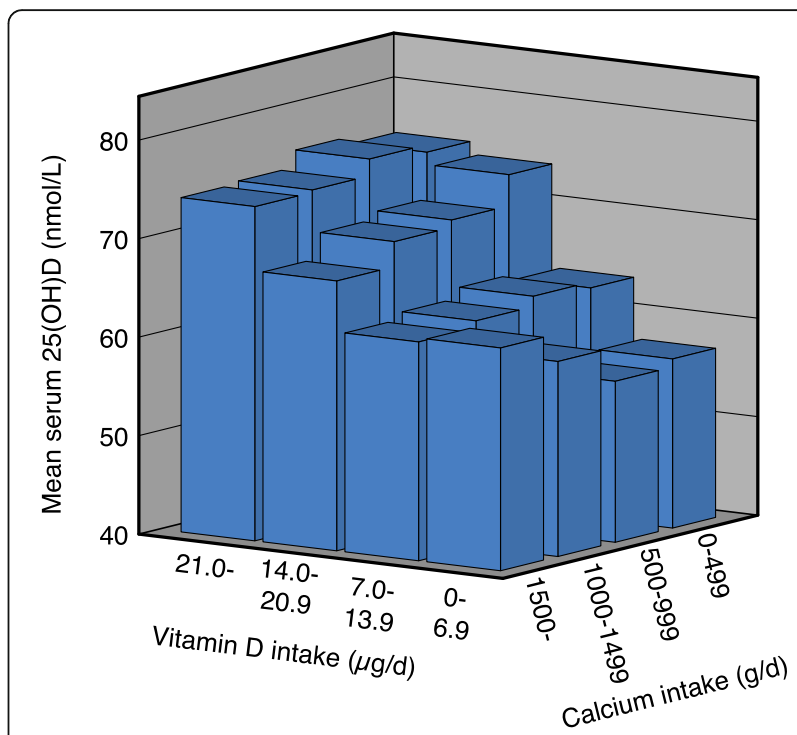

Fig. 3 Serum $25(\mathrm{OH}) \mathrm{D}$ in relation to vitamin $\mathrm{D}$ and calcium intakes in 5982 females who have not been on a sunny vacation last two months, and not taking solarium regularly

hydroxylase which starts the degradation and thus the elimination of 25(OH)D [1]. One would therefore expect that a low calcium intake should reduce, and not increase the serum 25(OH)D level. These PTH related mechanisms could therefore theoretically offer an explanation for the positive association between calcium intake and serum $25(\mathrm{OH}) \mathrm{D}$ in the females with low vitamin D intake. However, since the same patters of relation between calcium intake and serum $25(\mathrm{OH}) \mathrm{D}$ were seen when stratifying these females according to serum PTH levels, this cannot be the explanation.

The main calcium source is dairy products and subjects with a high calcium intake therefore also have a high phosphate intake, which will trigger the secretion of fibroblast growth factor 23 (FGF23). FGF23 will reduce the intestinal phosphate absorption by reducing the $1,25(\mathrm{OH})_{2} \mathrm{D}$ level through increased catabolism of $1,25(\mathrm{OH})_{2} \mathrm{D}$ as well as $25(\mathrm{OH}) \mathrm{D}$ [23]. Unfortunately we did not measure serum FGF23 nor serum phosphate and this explanation therefore purely speculative. Another explanation could be that the absorption of vitamin $\mathrm{D}$ was reduced by a high calcium intake which thereby would be associated with a lower serum $25(\mathrm{OH}) \mathrm{D}$ level. The absorption of vitamin $\mathrm{D}$ is assumed to be through passive diffusion as well as by membrane carriers, and may be increased by concomitant fat ingestion [24]. Furthermore, intestinal calcium ingestion may, by the formation of calcium-fatty acid soaps, which are excreted in the faeces, cause a slight reduction in intestinal fat absorption [25]. However, this reduction is less than $5 \mathrm{~g} / \mathrm{d}$ [26], which is probably too low to significantly affect the vitamin $\mathrm{D}$ absorption 
Table 3 Serum PTH in relation to calcium and vitamin D intakes in all subjects and gender specific in 1917 subjects in the sub-study

\begin{tabular}{|c|c|c|c|c|c|c|c|c|}
\hline & \multicolumn{2}{|c|}{$\begin{array}{l}\text { Calcium intake§ } \\
<500 \mathrm{mg} / \mathrm{d}\end{array}$} & \multicolumn{2}{|c|}{$\begin{array}{l}\text { Calcium intake§ } \\
500-999 \mathrm{mg} / \mathrm{d}\end{array}$} & \multicolumn{2}{|c|}{$\begin{array}{l}\text { Calcium intake§ } \\
1000-1499 \mathrm{mg} / \mathrm{d}\end{array}$} & \multicolumn{2}{|c|}{$\begin{array}{l}\text { Calcium intake§ } \\
>1499 \mathrm{mg} / \mathrm{d}\end{array}$} \\
\hline & $\mathrm{n}$ & Serum PTH (pmol/L) & $\mathrm{n}$ & Serum PTH (pmol/L) & $\mathrm{n}$ & Serum PTH (pmol/L) & $n$ & Serum PTH (pmol/L) \\
\hline \multicolumn{9}{|l|}{ All subjectsł } \\
\hline \multicolumn{9}{|c|}{ Vitamin D intake $(\mathrm{ug} / \mathrm{d}) \S$} \\
\hline$<7.0$ & 86 & $6.3(5.8,6.9)$ & 230 & $5.9(5.6,6.2)$ & 125 & $5.8(5.5,6.2)$ & 53 & $5.7(5.0,6.5)$ \\
\hline 7.0-13.9 & 44 & $6.6(5.7,7.4)$ & 225 & $5.9(5.7,6.2)$ & 236 & $5.9(5.6,6.1)$ & 119 & $6.0(5.6,6.4)$ \\
\hline $14.0-20.9$ & 15 & $7.4(5.0,9.8)$ & 85 & $5.8(5.4,6.3)$ & 130 & $5.6(5.3,6.0)$ & 104 & $5.8(5.3,6.2)$ \\
\hline$>20.9$ & 16 & $5.7(4.5,6.9)$ & 143 & $5.7(5.4,6.1)$ & 151 & $5.4(5.0,5.9)$ & 155 & $5.3(5.1,5.6)$ \\
\hline \multicolumn{9}{|l|}{ Males $\neq$} \\
\hline \multicolumn{9}{|c|}{ Vitamin D intake $(\mathrm{ug} / \mathrm{d}) \S$} \\
\hline$<7.0$ & 28 & $6.9(5.6,8.2)$ & 92 & $5.8(5.4,6.2)$ & 44 & $5.8(5.2,6.5)$ & 19 & $5.9(4.4,7.5)$ \\
\hline $7.0-13.9$ & 21 & $7.0(5.4,8.6)$ & 103 & $6.1(5.6,6.6)$ & 107 & $6.0(5.6,6.4)$ & 66 & $6.1(5.6,6.7)$ \\
\hline $14.0-20.9$ & 4 & $5.7(4.4,6.9)$ & 33 & $5.6(4.9,6.4)$ & 56 & $5.6(5.0,6.2)$ & 50 & $6.1(5.4,6.8)$ \\
\hline$>20.9$ & 4 & $5.7(1.2,9.5)$ & 68 & $5.6(5.2,6.0)$ & 62 & $5.6(4.5,6.7)$ & 71 & $5.2(4.9,5.6) \dagger$ \\
\hline \multicolumn{9}{|l|}{ Femalesł } \\
\hline \multicolumn{9}{|c|}{ Vitamin D intake $(\mathrm{ug} / \mathrm{d}) \S$} \\
\hline$<7.0$ & 58 & $6.1(5.6,6.6)$ & 138 & $6.0(5.6,6.4)$ & 81 & $5.8(5.4,6.2)$ & 34 & $5.6(4.7,6.5)$ \\
\hline $7.0-13.9$ & 23 & $6.1(5.3,6.9)$ & 122 & $5.8(5.5,6.1)$ & 129 & $5.8(5.4,6,2)$ & 53 & $5.8(5.2,6.4)$ \\
\hline $14.0-20.9$ & 11 & $8.0(4.7,11.4)$ & 52 & $6.0(5.3,6.6)$ & 74 & $5.7(5.3,6.1)$ & 54 & $5.4(5.0,5.9) \#$ \\
\hline$>20.9$ & 12 & $5.7(4.2,7.2)$ & 75 & $5.8(5.3,6.3)$ & 89 & $5.3(5.0,5.7)$ & 84 & $5.4(5.0,5.8)$ \\
\hline
\end{tabular}

$\# P<0.05$. Linear trend for serum PTH across calcium intake groups without adjustments

$+P<0.05$. Linear trend for serum PTH across vitamin D intake groups without adjustments as well as with sex, age, BMI and month of blood sampling (using dummy variables) as covariates

₹ Subjects in the Tromsø study with valid food frequency questionnaires, serum 25(OH)D measurement, not been on a sunny vacation last 2 months, not taking solarium regularly, with valid serum PTH measurement, and with serum calcium $<2.51 \mathrm{mmol} / \mathrm{L}$.

$\S$ Including supplements

The data are mean $(95 \% \mathrm{Cl})$. The $\mathrm{P}$ values are adjusted for multiple testing with a factor of 4

and can therefore hardly explain our findings. Additionally, we have no plausible hypotheses for why the positive association between calcium intake and serum $25(\mathrm{OH}) \mathrm{D}$ in subjects with low vitamin $\mathrm{D}$ intake was seen in women only, since there was no major gender differences regarding calcium and vitamin D intakes, age, BMI and PTH. If our findings are not the results of unaccounted for confounding, we therefore have to postulate the existence of unknown physiological process that regulate the vitamin $\mathrm{D}$ metabolism in response to calcium intake. In this regard the concept of the personal vitamin $\mathrm{D}$ response index should be considered [27]. According to this concept, the molecular response to supplementation with vitamin $\mathrm{D}$, such as changes in the epigenetic status and the respective transcription of genes, varies considerably between individuals. Hence, the measured serum $25(\mathrm{OH}) \mathrm{D}$ may not necessarily reflect the true impact of vitamin $D$ and calcium supplementation on vitamin D metabolism in a given individual.

Our study was purely observational and we can therefore not imply causality between calcium intake and the serum 25(OH)D level. This has to be tested in randomized controlled trials (RCTs) for which there are only a few relevant ones. Thus, in a study by Goussous et al., 52 subjects were given $800 \mathrm{IU}$ vitamin $\mathrm{D} / \mathrm{d}$ and randomized to $500 \mathrm{mg}$ calcium twice daily or placebo for 90 days. In the calcium group the mean serum 25(OH)D increased $16.2 \mathrm{nmol} / \mathrm{L}$ versus $17.4 \mathrm{nmol} / \mathrm{L}$ in the control group [16]. Similarly, in a study by McCullough et al. 92 subjects were randomized to $800 \mathrm{IU}$ vitamin $\mathrm{D} / \mathrm{d}, 2000 \mathrm{mg}$ calcium, both or placebo for 6 months. The increase in serum $25(\mathrm{OH}) \mathrm{D}$ was almost identical, 25 and $26 \mathrm{nmol} / \mathrm{L}$ respectively, in those with and without additional calcium [17]. In a study by Grant et al. on prevention of low trauma fractures, 5292 subjects were randomized to $800 \mathrm{IU}$ vitamin $\mathrm{D} / \mathrm{d}, 1000 \mathrm{mg}$ calcium/d, both or placebo, and serum $25(\mathrm{OH}) \mathrm{D}$ measured before and after one year in a subgroup of 60 subjects. In those allocated to combined vitamin $\mathrm{D}$ and calcium, serum $25(\mathrm{OH}) \mathrm{D}$ rose by $24.0 \mathrm{nmol} / \mathrm{L}$, whereas the increase in those given vitamin $\mathrm{D}$ alone was $24.3 \mathrm{nmol} / \mathrm{L}$ [18]. And finally, in a study by Cashman et al. including 
Table 4 Serum 25(OH)D in relation to calcium and vitamin D intakes in all subjects and gender specific in 1917 subjects in the sub-study

\begin{tabular}{|c|c|c|c|c|c|c|c|c|}
\hline & \multicolumn{2}{|c|}{$\begin{array}{l}\text { Calcium intake§ } \\
<500 \mathrm{mg} / \mathrm{d}\end{array}$} & \multicolumn{2}{|c|}{$\begin{array}{l}\text { Calcium intake§ } \\
500-999 \mathrm{mg} / \mathrm{d}\end{array}$} & \multicolumn{2}{|c|}{$\begin{array}{l}\text { Calcium intake } \\
1000-1499 \mathrm{mg} / \mathrm{d}\end{array}$} & \multicolumn{2}{|c|}{$\begin{array}{l}\text { Calcium intake } \\
>1499 \mathrm{mg} / \mathrm{d}\end{array}$} \\
\hline & $\mathrm{n}$ & $\begin{array}{l}\text { Serum 25(OH)D } \\
\text { (nmol/L) }\end{array}$ & $\bar{n}$ & $\begin{array}{l}\text { Serum 25(OH)D } \\
(\mathrm{nmol} / \mathrm{L})\end{array}$ & $\mathrm{n}$ & $\begin{array}{l}\text { Serum 25(OH)D } \\
\text { (nmol/L) }\end{array}$ & $\bar{n}$ & $\begin{array}{l}\text { Serum 25(OH)D } \\
\text { (nmol/L) }\end{array}$ \\
\hline \multicolumn{9}{|l|}{ All subjectsł } \\
\hline \multicolumn{9}{|c|}{ Vitamin D intake $(\mathrm{ug} / \mathrm{d}) \S$} \\
\hline$<7.0$ & 86 & $59.4(55.4,63.5)$ & 230 & $60.4(57.9,62.9)$ & 125 & $63.8(60.2,67.4)$ & 53 & 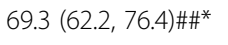 \\
\hline $7.0-13.9$ & 44 & $61.7(55.3,68.1)$ & 225 & $66.2(63.4,69.1)$ & 236 & $66.2(63.6,68.8)$ & 119 & $65.3(62.0,68.6)$ \\
\hline 14.0-20.9 & 15 & $81.6(70.3,92.8)$ & 85 & $75.1(69.9,80.2)$ & 130 & $71.2(67.7,74.7)$ & 104 & $67.8(64.1,71.4) \#^{*}$ \\
\hline$>20.9$ & 16 & $81.1(68.0,94.2) \dagger$ & 143 & $74.5(71.3,77.6) \dagger$ & 151 & $76.6(73.5,79.8) \dagger$ & 155 & $75.4(72.4,78.5) \dagger$ \\
\hline \multicolumn{9}{|l|}{ Malesł } \\
\hline \multicolumn{9}{|c|}{ Vitamin D intake (ug/d)§ } \\
\hline$<7.0$ & 28 & $58.7(51.2,65.5)$ & 92 & $59.4(55.7,63.1)$ & 44 & $57.8(53.1,62.6)$ & 19 & $54.6(45.9,63.2)$ \\
\hline $7.0-13.9$ & 21 & $56.6(46.6,66.6)$ & 103 & $63.3(59.4,67.1)$ & 107 & $63.8(60.0,67.6)$ & 66 & $61.8(57.4,66.2)$ \\
\hline $14.0-20.9$ & 4 & $76.6(50.1,103.0)$ & 33 & $74.4(64.2,84.6)$ & 56 & $67.1(62.4,71.8)$ & 50 & $61.6(56.3,66.9) \#^{*}$ \\
\hline$>20.9$ & 4 & $81.8(35.2,128.5)$ & 68 & $75.7(70.6,80.8)+$ & 62 & $75.2(70.9,79.4) \dagger$ & 71 & $71.0(67.3,74.7) \dagger$ \\
\hline \multicolumn{9}{|l|}{ Females $\neq$} \\
\hline \multicolumn{9}{|c|}{ Vitamin D intake (ug/d)§ } \\
\hline$<7.0$ & 58 & $59.8(54.6,64.9)$ & 138 & $61.1(57.8,64.4)$ & 81 & $67.1(62.2,71.9)$ & 34 & $77.5(68.5,86.6) \# \#^{* *}$ \\
\hline $7.0-13.9$ & 23 & $66.3(58.0,74.7)$ & 122 & $68.7(64.6,72.8)$ & 129 & $68.2(64.7,71.7)$ & 53 & $69.7(64.7,74.7)$ \\
\hline $14.0-20.9$ & 11 & $83.4(68.7,98.1)$ & 52 & $75.5(69.7,81.2)$ & 74 & $74.3(69.3,79.3)$ & 54 & $73.4(68.7,78.2)$ \\
\hline$>20.9$ & 12 & $80.9(65.4,96.3) \dagger$ & 75 & $73.3(69.4,77.3) \dagger$ & 89 & $77.7(73.2,82.2) \dagger$ & 84 & $79.2(74.6,83.7)$ \\
\hline
\end{tabular}

$\# P<0.05, \# \#<0.01$. Linear trend for serum 25(OH)D across calcium $D$ intake groups without adjustments

${ }^{*} P<0.05,{ }^{* *} P<0.01$. Linear trend for serum $25(\mathrm{OH}) \mathrm{D}$ across calcium intake groups with sex, age, BMI and month of blood sampling (using dummy variables) as covariates

$\dagger P<0.001$. Linear trend for serum 25(OH)D across vitamin D intake groups without adjustments as well as with sex, age, BMI and month of blood sampling (using dummy variables) as covariates

\# Subjects in the Tromsø study with valid food frequency questionnaires, serum 25(OH)D measurement, not been on a sunny vacation last 2 months, not taking solarium regularly, with valid serum PTH measurement, and with serum calcium $<2.51 \mathrm{mmol} / \mathrm{L}$

$\S$ Including supplements

The data are mean $(95 \% \mathrm{Cl})$. The $\mathrm{P}$ values are adjusted for multiple testing with a factor of 4

125 subjects stratified according to calcium intake and given $800 \mathrm{IU}$ vitamin $\mathrm{D} / \mathrm{d}$, there was no evidence of a $25(\mathrm{OH}) \mathrm{D}$ sparing effect of high calcium intake. However, in the subjects with a low calcium intake $(<700 \mathrm{mg} /$ d) the increase in mean serum $25(\mathrm{OH}) \mathrm{D}$ was nonsignificantly higher than in those with a high calcium intake (> $1000 \mathrm{mg} / \mathrm{d})(26.1 \mathrm{nmol} / \mathrm{L}$ vs $20.0 \mathrm{nmol} / \mathrm{l})$ [15].

All of these studies have included relatively few subjects. Given that the effect probably is small and may be different in subgroups, larger studies are needed to settle this question. It is unlikely that a large RCT will be designed specifically for this purpose, but there is at least one large study performed with vitamin D intervention with or without additional calcium and with serum 25(OH)D measurements. Thus, in the study by Baron et al. 2259 participants with recently diagnosed adenomas and no known colorectal polyps remaining after colonoscopy, were assigned to vitamin D $1000 \mathrm{IU} /$ d, calcium $1200 \mathrm{mg} / \mathrm{d}$, both or neither, with recurrence of adenoma as primary endpoint. Serum $25(\mathrm{OH}) \mathrm{D}$ was measured at baseline and after 1 year. However, the serum $25(\mathrm{OH}) \mathrm{D}$ increase in the vitamin $\mathrm{D}$ alone vs the vitamin D plus calcium groups was not (as far as we have been able to find) specifically reported in their publications [28].

Our study has several limitations. Firstly, as an observational study we cannot conclude about causality. We did not measure serum $1,25(\mathrm{OH})_{2} \mathrm{D}$ and 24 , $25(\mathrm{OH})_{2} \mathrm{D}$, nor did we do gene-expression studies, which would have been important from a mechanistically point of view. Our subjects had a mean age of 58 years and only $29.6 \%$ were vitamin D deficient (serum $25(\mathrm{OH}) \mathrm{D}<50 \mathrm{nmol} / \mathrm{L})$. Our results are therefore not relevant for children at risk of rickets. Although our study was population based, the subjects in the substudy were highly selected with mean age $\sim 70$ years and with mean serum $25(\mathrm{OH}) \mathrm{D}$ as high as $70 \mathrm{nmol} / \mathrm{L}$. On the other hand, our study also has strengths as we included a large number of subjects, which made it meaningful to do stratified analyses. The observation 


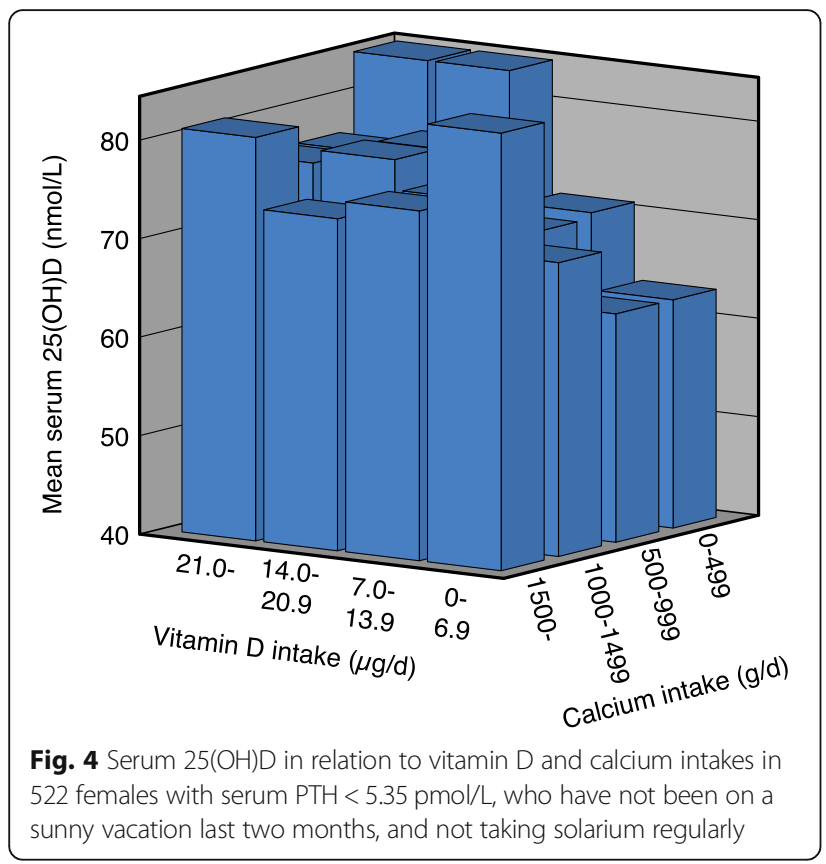

of a negative association between calcium intake and serum $25(\mathrm{OH}) \mathrm{D}$, at least in subjects with adequate vitamin $\mathrm{D}$ intake, was statistically highly significant and might reflect unknown aspects of vitamin D metabolism. Direct or indirect inhibition of 25-hydroxylation and/ or stimulation of $25(\mathrm{OH}) \mathrm{D}$ degradation by calcium are the most obvious pathways, that potentially could be verified by gene-expression studies.

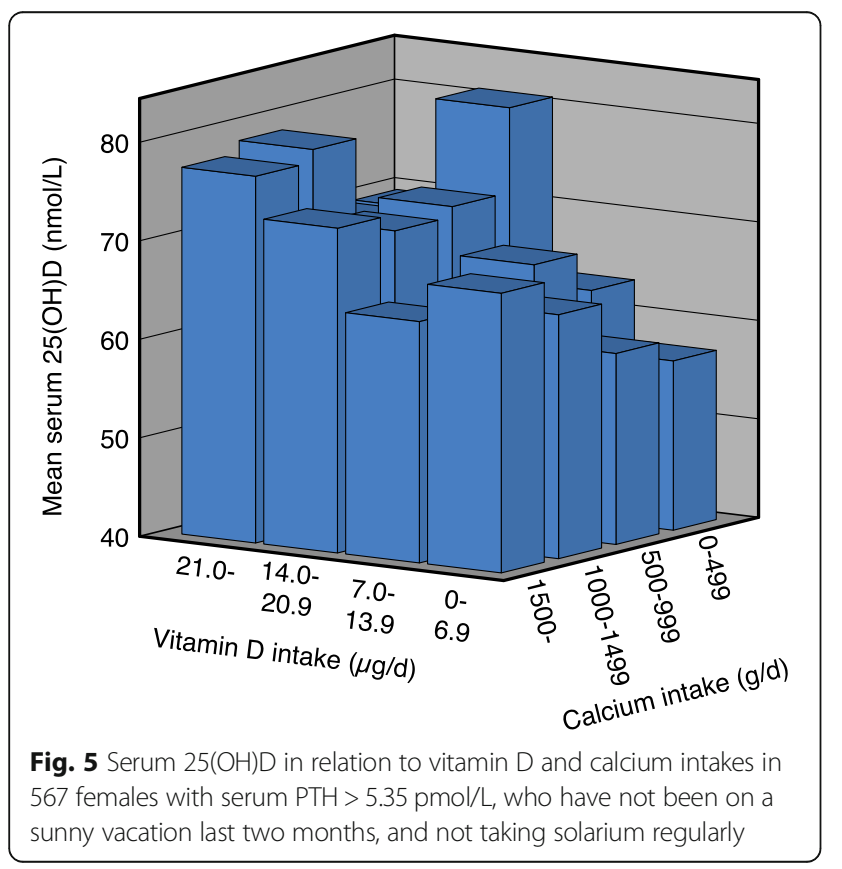

\section{Conclusions}

We have found serum $25(\mathrm{OH}) \mathrm{D}$ to decrease with increasing calcium intake, at least in subjects with an adequate intake of vitamin D. Our findings are hard to explain, but if confirmed in large intervention trials, studies aiming at explaining the underling mechanisms should be encouraged.

\section{Supplementary information}

Supplementary information accompanies this paper at https://doi.org/10. 1186/s40795-020-00381-4.

Additional file 1: Table S1. A linear regression model with serum $25(\mathrm{OH}) \mathrm{D}$ as dependent variable and sex, age, BMl vitamin D and calcium intakes as covariates.

\section{Abbreviations}

BMI: Body mass index; FGF23: Fibroblast growth factor 23; PTH: Parathyroid hormone; RCTs: Randomized controlled trials; $1,25(\mathrm{OH})_{2} \mathrm{D}$ : 1,25dihydroxyvitamin D; 25(OH)D: 25-hydroxyvitamin D

\section{Acknowledgements}

The superb assistance from the staff at the Department of Medical Biochemistry at the University Hospital of North Norway is gratefully acknowledged.

\section{Authors' contributions}

Conceptualization, methodology, investigation and resources R.J. and G.G.; Formal analysis, project administration and original draft preparation, R.J.; Review, editing, and funding acquisition R.J. and G.G. Both authors have read and approved the manuscript.

\section{Funding}

The study was supported by grants from the North Norway Regional Health Authorities (grant number SFP1277-16) and UiT The Arctic University of Norway.

\section{Availability of data and materials}

The datasets used in the study are not available publicly but can be made available upon application to the Tromsø Study (tromsous@uit.no) (www. tromsoundersokelsen.no).

\section{Ethics approval and consent to participate}

The Troms $\varnothing$ study is approved by the Regional Committee for Medical and Health Research Ethics (REK Nord) and only participants with valid written consent were included.

\section{Consent for publication}

Not applicable.

\section{Competing interests}

The authors declare that there is no conflict of interest that could be perceived as prejudicing the impartiality of the research reported.

Received: 26 June 2020 Accepted: 9 September 2020 Published online: 02 November 2020

\section{References}

1. DeLuca HF. Overview of general physiologic features and functions of vitamin D. Am J Clin Nutr. 2004;80:1689S-96S.

2. Holick MF, Binkley NC, Bischoff-Ferrari HA, Gordon CM, Hanley DA, Heaney RP, Murad MH, Weaver CM. Endocrine Society. Evaluation, treatment, and prevention of vitamin D deficiency: an Endocrine Society clinical practice guideline. J Clin Endocrinol Metab. 2011;96:1911-30.

3. Ross AC, Manson JE, Abrams SA, Aloia JF, Brannon PM, Clinton SK, DurazoArvizu RA, Gallagher JC, Gallo RL, Jones G, et al. The 2011 report on dietary 
reference intakes for calcium and vitamin $\mathrm{D}$ from the Institute of Medicine what clinicians need to know. J Clin Endocrinol Metab. 2011;96:53-8.

4. Creo AL, Thacher TD, Pettifor JM, Strand MA, Fischer PR. Nutritional rickets around the world: an update. Paediatrics Int Child Health. 2017;37:84-98.

5. Heaney RP. Vitamin D and calcium interactions: functional outcomes. Am J Clin Nutr. 2008:88:541S-4S.

6. Anderson PH, Lee AM, Anderson SM, Sawyer RK, O'Loughlin PD, Morris HA. The effect of dietary calcium on 1,25(OH)2D3 synthesis and sparing of serum 25(OH)D3 levels. J Steroid Biochem Mol Biol. 2010;121:288-92.

7. Clements MR, Johnson L, Fraser DR. A new mechanism for induced vitamin D deficiency in calcium deprivation. Nature. 1987;325:62-5.

8. Davies M, Heys SE, Selby PL, Berry JL, Mawer EB. Increased catabolism of 25hydroxyvitamin $\mathrm{D}$ in patients with partial gastrectomy and elevated 1,25dihydroxyvitamin D levels. Implications for metabolic bone disease. N Engl J Med. 1997:82:209-12.

9. Lips P. Interaction between vitamin D and calcium. Scand J Clin Lab Invest Suppl. 2012;243:60-4.

10. Olmos JM, Hernández JL, García-Velasco P, Martínez J, Llorca J, GonzálezMacías J. Serum 25-hydroxyvitamin D, parathyroid hormone, calcium intake, and bone mineral density in Spanish adults. Osteoporos Int. 2016;27:105-13.

11. Kinyamu HK, Gallagher JC, Rafferty KA, Balhorn KE. Dietary calcium and vitamin $D$ intake in elderly women: effect on serum parathyroid hormone and vitamin D metabolites. Am J Clin Nutr. 1998:67:342-8.

12. Hill TR, Cotter AA, Mitchell S, Boreham CA, Dubitzky W, Murray L, Strain JJ, Flynn A, Robson PJ, Wallace JM, et al. Vitamin D status and its determinants in adolescents from the Northern Ireland young hearts 2000 cohort. Br J Nutr. 2008:99:1061-7.

13. Andersen R, Mølgaard C, Skovgaard LT, Brot C, Cashman KD, Jakobsen J, Lamberg-Allardt C, Ovesen L. Pakistani immigrant children and adults in Denmark have severely low vitamin D status. Eur J Clin Nutr. 2008;62:625-34.

14. Berlin T, Björkhem I. Effect of calcium intake on serum levels of 25hydroxyvitamin D3. Eur J Clin Investig. 1988;18:52-5.

15. Cashman KD, Hayes A, O'Donovan SM, Zhang JY, Kinsella M, Galvin K, Kiely $M$, Seamans KM. Dietary calcium does not interact with vitamin $D_{3}$ in terms of determining the response and catabolism of serum 25-hydroxyvitamin D during winter in older adults. Am J Clin Nutr. 2014;99:1414-23.

16. Goussous R, Song L, Dallal GE, Dawson-Hughes B. Lack of effect of calcium intake on the 25-hydroxyvitamin d response to oral vitamin D3. J Clin Endocrinol Metab. 2005;90:707-11.

17. McCullough ML, Bostick RM, Daniel CR, Flanders WD, Shaukat A, Davison J Rangaswamy U, Hollis BW. Vitamin D status and impact of vitamin D3 and/ or calcium supplementation in a randomized pilot study in the southeastern United States. J Am Coll Nutr. 2009;28:678-86.

18. Grant AM, Avenell A, Campbell MK, MCDonald AM, MacLennan GS, McPherson GC, Anderson FH, Cooper C, Francis RM, Donaldson C, et al. Oral vitamin D3 and calcium for secondary prevention of low-trauma fractures in elderly people (randomised evaluation of calcium or vitamin D, RECORD): a randomised placebo-controlled trial. Lancet. 2005;365:1621-8.

19. Jacobsen BK, Eggen AE, Mathiesen EB, Wilsgaard T, Njølstad I. Cohort profile: the Tromso study. Int J Epidemiol. 2012;41:961-7.

20. Carlsen MH, Lillegaard IT, Karlsen A, Blomhoff R, Drevon CA, Andersen LF. Evaluation of energy and dietary intake estimates from a food frequency questionnaire using independent energy expenditure measurement and weighed food records. Nutr J. 2010;9:37.

21. Lundblad MW, Andersen LF, Jacobsen BK, Carlsen MH, Hjartåker A, Grimsgaard S, Hopstock LA. Energy and nutrient intakes in relation to National Nutrition Recommendations in a Norwegian population-based sample: the Tromsø study 2015-16. Food Nutr Res. 2019;10:63.

22. Sollid ST, Hutchinson MY, Fuskevåg OM, Figenschau Y, Joakimsen RM, Schirmer H, Njølstad I, Svartberg J, Kamycheva E, Jorde R. No effect of highdose vitamin D supplementation on glycemic status or cardiovascular risk factors in subjects with prediabetes. Diabetes Care. 2014;37:2123-31.

23. Takashi Y, Fukumoto S. Phosphate-sensing and regulatory mechanism of FGF23 production. J Endocrinol Investig. 2020. https://doi.org/10.1007/ s40618-020-01205-9 [Epub ahead of print].

24. Silva MC, Furlanetto TW. Intestinal absorption of vitamin D: a systematic review. Nutr Rev. 2018;76:60-76.

25. Boon N, Hul GB, Stegen JH, Sluijsmans WE, Valle C, Langin D, Viguerie $\mathrm{N}_{\text {, }}$ Saris WH. An intervention study of the effects of calcium intake on faecal fat excretion, energy metabolism and adipose tissue mRNA expression of lipidmetabolism related proteins. Int J Obes. 2007;31:1704-12.
26. Christensen R, Lorenzen JK, Svith CR, Bartels EM, Melanson EL, Saris WH, Tremblay A, Astrup A. Effect of calcium from dairy and dietary supplements on faecal fat excretion: a meta-analysis of randomized controlled trials. Obes Rev. 2009;10:475-86

27. Carlberg C, Haq A. The concept of the personal vitamin D response index. J Steroid Biochem Mol Biol. 2018;175:12-7.

28. Baron JA, Barry EL, Mott LA, Rees JR, Sandler RS, Snover DC, Bostick RM, Ivanova A, Cole BF, Ahnen DJ, et al. A trial of calcium and vitamin D for the prevention of colorectal adenomas. N Engl J Med. 2015;373:1519-30.

\section{Publisher's Note}

Springer Nature remains neutral with regard to jurisdictional claims in published maps and institutional affiliations.
Ready to submit your research? Choose BMC and benefit from:

- fast, convenient online submission

- thorough peer review by experienced researchers in your field

- rapid publication on acceptance

- support for research data, including large and complex data types

- gold Open Access which fosters wider collaboration and increased citations

- maximum visibility for your research: over $100 \mathrm{M}$ website views per year

At BMC, research is always in progress.

Learn more biomedcentral.com/submissions 